\title{
O hiphopowej intertekstualności jako rozmowie. Rap i popkultura: follow-upy i hashtagi
}

Adrianna Chorąży 


\section{O hiphopowej intertekstualności jako rozmowie. Rap i popkultura: follow-upy i hashtagi}

Adrianna Chorąży

TEKSTY DRUGIE 2017, NR 5, S. 129-146

DOI: 10.18318/td.2017.5.8

\section{Wstęp. Komentarz metodologiczny}

W artykule chciałabym przybliżyć temat intertekstualności hiphopowej', analizując techniki raperskie, które służą do wprowadzania tychże elementów. Intertekstualność przejawia się w hip-hopie wielowarstwo: występuje w warstwie muzycznej (sample ${ }^{2}$, cuty ${ }^{3}$ ), warstwie

1 Pojęć hip-hop oraz rap używam zamiennie wedle przyjętej konwencji. Odchodzę również od dość popularnego w Polsce sposobu otwierania artykułów na temat hip-hopu komentarzem socjologiczno-historycznym. Choćby zob. Hip-hop w Polsce. Od blokowisk do kultury popularnej, red. M. Miszczyński, Wydawnictwa UW, Warszawa 2014; Antologia polskiego rapu, red. A. Cała, D. Węcławek i in., NCK, Warszawa 2015.

2 "Elektroniczny, klawiszowy instrument muzyczny, odgrywający wcześniej nagrane próbki dźwięków (sample) instrumentów akustycznych oraz innych dźwięków - nie tylko muzycznych. Producenci do samplowania wykorzystują również fragmenty filmów, programów telewizyjnych lub zarejestrowanych przez siebie dźwięków" - Słownik, w: Antologia polskiego rapu, s. 22.

3 „Fragment wokalny z cudzego bądź własnego nagrania wskreczowany przez didżeja do utworu jako uzupełnienie zwrotki czy też refren albo jego osobna partia", tamże, s. 8.

\author{
Adrianna Chorąży \\ - absolwentka VLO \\ im. A. Witkowskiego \\ w Krakowie, obecnie \\ studentka II roku \\ studiów drugiego \\ stopnia polonistyki- \\ -komparatystyki \\ w ramach MISH na \\ UJ. Członkini Rady \\ Programowej III Ma- \\ łopolskiego Kongresu \\ Kobiet. Publikowała \\ m.in. w "Masce", \\ „Bez porównania”, \\ "MKW". Jej zaintere- \\ sowania badawcze \\ koncentrują się wokół \\ zagadnień związa- \\ nych z humanistyką \\ cyfrową. Kontakt: \\ chorazy.adrianna@ \\ gmail.com
}


głosowej (naśladowanie sposobów i stylów mówienia/rapowania), wizualnej (teledyski) i tekstowej (follow-up, hashtag). Artykuł koncentruje się na tej ostatniej, przy czym z jednej strony analizuje hermetyczną wewnątrzrapową intertekstualność, a z drugiej odniesienia do popkultury.

Intertekstualność to termin po raz pierwszy użyty przez Julię Kristevą w 1969 roku na określenie dynamicznego charakteru słowa i relacyjności tekstu, który nie stanowi formy zamkniętej, ale zawsze funkcjonuje w nieskończonym dialogu z innymi tekstami. Michał Głowiński zawęża termin intertekstualność do intencjonalnych relacji tekstowych, w których odwołanie w hipertekście do hipotekstu zawsze odgrywa rolę w budowaniu znaczeń ${ }^{4}$. W tym sensie będziemy mieć do czynienia z dekontekstualizacją (wyjęcie elementu z pierwotnej semantyki) i rekontekstualizacją sensu (wprowadzenie elementu w nowy kontekst). Ryszard Nycz rozwija koncepcję Głowińskiego i uznaje, że intertekstualność nie ogranicza się tylko do „wewnątrzliterackich odniesień" i stylami mowy” oraz także intersemiotycznych powiązań z „pozadyskursywnymi mediami sztuki i komunikacji (plastyka, muzyka, film, komiks etc.)"6. Obaj badacze, aby określić potencjalność odczytywań intertekstualnych?', posługują się pojęciem „interpretanta” Michaela Riffaterre, czyli ramy kontekstowej utworzonej przez autora wokół odniesienia do hipotekstu. Względność dostrzeżenia intertekstualności przez odbiorcę wynika ze względności jego kompetencji ${ }^{8}$. Podobnie Brian Ott i Cameron Walter, podejmując temat intertekstualności, zwracają uwagę, że jest ona jednocześnie strategią konstruowania tekstu, jak i sposobem czytania9. Również Gerard Genette, wprowadzając ideę palimpsestowego modelu intertekstualności, pisał o jej znaczeniotwórczym aspekcie i względności interpretacji, zależnej od

\footnotetext{
4 M. Głowiński O intertekstualności, „Pamiętnik Literacki” 1986 z. 4, S. 75.

5 R. Nycz Intertekstualność i jej zakresy: teksty, gatunki, światy, „Pamiętnik literacki” 1990 z. 2, S. 97.

6 Tamże.

7 O potencjalności odbioru pisze Aleksandra Okopień-Sławińska, według Głowińskiego intertekstualność pogłębia ową potencjalność. Zob. M. Głowiński O intertekstualności, s. 93.

8 Także zob. A. Hejmej Muzyka w literaturze. Perspektywy komparatystyki interdyscyplinarnej, Universitas, Kraków 2012, s. 17-19.

9 Zob. B. Ott, C. Walter Intertextuality: Interpretive Practice and Textual Strategy " "Cultural Studies in Media Communication" 2000 No. 17/4.
} 
kompetencji kulturowych odbiorcy, ale i od sposobów wprowadzania hipotekstu przez autora ${ }^{10}$.

Przed podjęciem próby charakteryzacji intertekstualności w hip-hopie należy poczynić dwa rozpoznania wstępne. Po pierwsze, rap uznaję - za zwolennikami takiej tezy ${ }^{11}$ - za gatunek literacki, ponieważ realizuje on powszechnie przyjęte wyznaczniki literackości. Organizuje strukturę tekstu w sposób inny niż typowa sytuacja komunikacyjna (np. hashtagowanie $^{12}$, braggadacio ${ }^{13}$; mimo silnego nastawienia na autentyczność przekazu wprowadza elementy fikcji literackiej (np. storytelling ${ }^{14}$ ); fikcjonalność

10 Zob. G. Genette Palimpsesty. Literatura drugiego stopnia, przeł. A. Milecki, w: Współczesna teoria badań za granicq, oprac. H. Markiewicz, t. 4, cz. 2, Wydawnictwo Literackie, Kraków 1992.

11 Klasyfikowanie rapu jako gatunku literackiego, a konkretniej poezji, wciąż pozostaje kwestią sporną. Przykładowo finlandzka badaczka Elina Westinen, pisząc o hip-hopie, nie określa go nigdy poezją ani literaturą. Zob. E. Westinen The Discursive Construction of Authenticity. Resources, Scales and Polycentricity in Finnish Hip Hop Culture, Jyväskylä Yliopisto, Jyväskylä 2014. Jednakże najbardziej zasłużeni badacze z zakresu hip-hop studies włączają rap w obręb literatury. Zob. A. Bradley Book of Rhymes. The Poetics of Hip Hop, Basic Civitas Books, New York 2009, s. IX-XXI; D. Caplan Rhyme's Challenge. Hip hop, poetry, and contemporary rhyming culture, Oxford University Press, New York 2014, s. 1-24. Klasyfikacja ta utrwala się również w innych pracach naukowych poświęconych, choćby częściowo, hip-hopowi. Zob. P. Giovannetti Dalla poesia in prosa al rap. Tradizioni e canoni metrici nella poesia italiana contemporanea, Interlinea, Novara 2008; S.B.A. Somers-Willett "Commercial Niggas Like Me": Spoken Word Poetry, Hip-Hop, and the Racial Politics of Going Mainstream, w: tejże The Cultural Politics Of Slam Poetry, University of Michigan Press, Michigan 2009, s. 96-133. W Polsce do tejże dyskusji bezpośrednio włączył się Arkadiusz Mastalski, który uznał rap za rodzaj współczesnej melorecytacji, a nie poezji. Zob. A.S. Mastalski Rap jako rodzaj współczesnej melorecytacji w: Hip-hop w Polsce..., s. 105-123. Pośrednio ten wątek podejmują (i opowiadają się za literackością rapu) tacy badacze jak Tomasz Kukołowicz czy Stanisław Wójtowicz. Zob. T. Kukołowicz Transkrypcja tekstów hip-hopowych (rapu) w świetle teorii wiersza, "Teksty Drugie" 2012 nr 6, s. 229-245; S. Wójtowicz O kierunkach w polskich badaniach literaturoznawczych nad hip-hopem, w: Hip-hop w Polsce..., s. $183-198$.

12 Humorystyczne, wieloznaczne słowa-klucze występujące na końcu wersów; zazwyczaj wyszczególnione, pojawiającą się przed nimi, przerwą na oddech. Twórcy Antologii polskiego rapu podają taką definicję: „pojedyncze słowo lub ciąg znaków poprzedzone symbolem \#. [...] W hiphopowych tekstach używane najczęściej jako połączenie kilku słów, nawiązanie do określonych osób lub sytuacji, wstawiane niejako w postaci zamiennika słowa «jak»". Zob. Słownik, S. 14 .

13 Technika polegająca na wychwalaniu samego siebie. Zob. tamże, s. 5-6. Stanisław Wójtowicz pokazuje, w jaki sposób plan treści uzupełnia się w planie formy. Zob. S. Wójtowicz O kierunkach..., s. 186-187.

14 Silnie narracyjny tekst; utwór jest opowieścią lub wykorzystuje elementy opowiadania. Twórcy Antologii polskiego rapu nie opisują tej techniki w Słowniku. 
często połączona jest z intertekstualnością i autotelicznością; estetyka hip-hopu pozostaje kwestią problematyczną, ponieważ nie podlega modernistycznej kategoryzacji ${ }^{15}$, a jej klasyfikacja wymaga przyjrzenia się fundamentalnej materii rapu ${ }^{16}$. Po drugie, należy zauważyć, że tekst rapowy konstruowany jest w inny sposób niż utwór poetycki (nie podlega zasadom sylabizmu, tonizmu czy sylabotonizmu), stąd też w procesie transkrypcji staje się amorficzny ${ }^{17}$. Nieregularność zapisu przeczy regularności rejestracji fonograficznej ${ }^{18}$, gdyż utwór organizowany jest przez problematyczne do zakodowania flow ${ }^{19}$. Hip-hop wytwarza własną organizację tekstu. Te dwie uwagi wstępne są niezbędne w trakcie refleksji nad intertekstualnością w hip-hopie, która jak dotąd była rozważana bez brania ich pod uwagę. Wydaje się, że włączenie rapu w obręb literatury przy jednoczesnym zasygnalizowaniu jego odrębności stylistycznej i konstrukcyjnej pozwala wstępnie sprecyzować i zaktualizować terminologię w kontekście intertekstualności.

15 Przykładowo Richard Shusterman redefiniuje modernistyczną kategorię estetyki w kontekście rapu, uznając, że przeżycie estetyczne łączy w sobie aspekt emocjonalny i społeczno-polityczny. Zob. R. Shusterman Piękna sztuka rapowania, przeł. A. Chmielewski, "Odra” 1995 nr 3, s. $23-29$.

Chodzi przykładowo o kategorię luzu, którą wprowadza Wójtowicz. Zob. S. Wójtowicz O kierunkach..., s. 187-188.

Propozycje zapisu tekstów hiphopowych wciąż pozostają problematyczne. Zob. P. Edwards How to rap. The Art and Science of the Hip-hop MC, Chicago Review Press, Chicago 2009; T. Kukołowicz Transkrypcja tekstów...; K. Adams, The musical analysis of hip-hop. w: The Cambridge Companion to Hip-Hop, pod red. J.A. Williams, Cambridge University Press, Cambridge 2015, S. $116-134$.

Uważam, że asylabizm w przypadku hip-hopu okazuje się regularny. Należy zauważyć, że pojedynczy wers (w zdecydowanej większości utworów) mieści się w 1,5 pętli muzycznej, czyli wykonawca potrzebuje około 3 sekund na zarapowanie linijki. Występuje (zazwyczaj w każdym wersie) średniówka dzieląca nie sylaby, ale czas potrzebny do wykonania wersu na pół. W obrębie wersu (zakończonego zawsze rymem) w utworze może mieścić się obojętnie jaka liczba sylab (bez zmian w podkładzie muzycznym) i nie wpłynie to na czas wykonywania wersu. Tekst porządkują modulacje głosowe rapera takie jak: tempo, sposób artykulacji, intonacja, przeciąganie i nakładanie na siebie głosek, przerwy. Idealna transkrypcja rapu wymagałaby więc zaznaczenia tychże cech, a tym samym prawdopodobnie inkluzywnego alfabetu. Kwestia zapisu utworu hiphopowego wymaga pogłębionych badań wersologicznych. 


\section{Intertekstualność w hip-hopie cz. 1: follow-up}

W polsko- ${ }^{20} \mathrm{i}$ anglojęzycznych ${ }^{21}$ artykułach z zakresu hip-hop studies ,intertekstualność" oznacza odniesienia do elementów (aluzji, cytatów etc.) zarówno wewnątrzhiphopowych, jak i pozahiphopowych. Natomiast wśród słuchaczy funkcjonują również takie określenia jak cuty i follow-upy. W wąskim ujęciu follow-up ,to dodatkowy smaczek, pokazujący inspiracje rapera, jego hołd kulturze. Polega na zacytowaniu wersu kolegi po fachu lub na użyciu jego parafrazy"22. W szerokim ujęciu odniesienie wykracza poza teksty hiphopowe:

To taka pewnego rodzaju luźna parafraza, świadoma inspiracja czyjąś działalnością. [...] W dodatku, nie zawsze [follow-upy - przyp. A.Ch.] niosą ze sobą przesłanie będące jakiegokolwiek rodzaju hołdem, a wręcz przeciwnie, są wytknięciem lub wyśmianiem.[...] Follow-upy mogą odnosić się praktyczne do wszystkiego, od wersów utworów muzycznych, przez ich tytuły, wywiady, poezję, prozę, po konkretne wydarzenia, czy grafiki. $^{23}$

Twórcy Antologii polskiego rapu opowiadają się za wąskim rozumieniem follow-upu i definiują go jako „nawiązanie do cudzego bądź własnego wersu czy utworu przez bezpośrednie przytoczenie lub sparafrazowanie go w tekście. Kolejny oprócz cutów sposób na pielęgnowanie hiphopowej historii, upamiętnienie dobrych linijek i cementowanie sceny" ${ }^{24}$. Pisze o tym również Stanisław Wójtowicz, który najpierw włącza cuty i follow-upy w obręb

20 Przykładowo zob. R. Picz Hip-hop - muzyka amatorów, czy wysoce profesjonalna forma komunikacji?, w: Amatorzy kontra profesjonaliści, red. A. Maj, "Zeszyty Komunikacji Kulturowej", Katowice 2009; A.S. Mastalski Rap jako rodzaj...; B. Maciejczyk Zwiq̨zki literatury sowizdrzalskiej z subkulturq hip-hopu. Intertekstualny dialog, "Tematy i Konteksty" 2016 nr 6/11.

Przykładowo zob. J.A. Williams Theoretical Approaches to Quotation in Hip-Hop Recordings, "Contemporary Music Review" 2014 No. 2/33; J. Kolarič Intertextuality and Allusion in Rap Lyrics, „Inquis” 2016 No. 1 na: https://inquisjournal.files.wordpress.com/2015/12/inquis_issue1_ may_2016.pdf(20.02.2017).

A. Ogłoza Jak zbudowany jest utwór hiphopowy? (16.04.2015) na: http://piwnyrap.pl/jak-zbudowany-jest-utwor-hiphopowy/ (20.02.2017)

A. Strzelecka Follow-up (maj 2013) na: http://swiadomysluchacz.blogspot.com/2013/05/follow-up-kicz.html (20.02.2017)

Antologia polskiego rapu, s. 11-12. 
„intertekstualności hip-hopowej”25, a następnie stawia tezę o hermetyczności rapu pisząc, że „intertekstualność w hip-hopie ma często charakter wewnątrzkulturowy, twórcy odnoszą się przede wszystkim do dorobku innych raperów $[\ldots]^{\prime 26}$.

Proponuję określenie follow-upu jako świadomego i najczęściej pozbawionego ramy kontekstowej odniesienia w hipertekście hiphopowym do hipotekstu hiphopowego, które polega na cytowaniu lub parafrazowaniu wersu/wersów. Kwestia marginalnej obecności ramy kontekstowej w przypadku posługiwania się follow-upem jest absolutnie kluczowa w trakcie refleksji nad intertekstualnością, co wykażę dalej, ponieważ pokazuje dwutorową dialogiczność w hip-hopie: uprzywilejowaną i wewnątrzśrodowiskową oraz uwarunkowaną kompromisami i pozaśrodowiskową. Z tej przyczyny, ale i z powodu specyficznej literackości rapu ${ }^{27}$, należy uznać, że follow-up jest elementem składowym złożonej intertekstualności, który wymaga wyodrębnienia. Szerokie definiowanie follow-upu byłoby nonsensem, ponieważ prawie zawsze funkcjonuje on w tekście inaczej niż pozostałe odniesienia. Jednakże nierozważnie byłoby również uznać, że w tej chwili follow-upy (jak wskazuje na to etymologia słowa: uzupełnienie, kontynuacja) mają tylko funkcje: upamiętniającą czy hołdującą. Występują również jako elementy humorystyczne, parodyczne, prześmiewcze, autopromocyjne etc. - i tym samym dalej (ale na różnych warunkach) tworzą rapowy kanon. Follow- upy podlegają więc normatywnemu rozumieniu intertekstualności, w obręb której, wbrew opinii Wójtowicza, raperzy włączają odniesienia również do rodzimej kultury. Hip-hop nawiązuje nie tylko do siebie samego, ale i do wszelkich innych tekstów kultury w tym do kultury popularnej. W najnowszych utworach rapowych takie odniesienia pojawiają się coraz częściej, co może sygnalizować, że pierwotnie silnie środowiskowy gatunek redefiniuje się z sublkulturowego na popkulturowy i tym samym podejmuje rozmowę z nowymi odbiorcami.

S. Wójtowicz O kierunkach..., s. 185.

Tamże, s. 192.

Myślę tutaj o wspomnianych problemach: literackości rapu oraz kompozycji tekstu. Specyficzność wydaje się wynikać z intrygującej kwestii badawczej: nieuświadomionej redefinicji literatury oralnej przez jednostki, należące do kultury wysoko piśmiennej. Analiza rapu (jak i slamu poetyckiego) pod kątem jego oralno-piśmiennych cech i naleciałości mogłaby zaowocować istotnymi wnioskami. 


\section{Intertekstualność w hip-hopie cz. 2: follow-up a \#popkultura}

W artykule na zilustrowanie złożonej intertekstualności tekstowej w hip-hopie posłużą utwory duetu Dwa Sławy ${ }^{28}$, przy czym główny nacisk zostanie położony na ich najnowszą płytę Dandys Flow, wydaną w styczniu 2017 roku nakładem wytwórni Embryo Nagrania. Pojawią się również odwołania do płyty powstałej dwa lata wcześniej Ludzie sztosy. Wybór ten motywowany jest względami praktycznymi. Po pierwsze, Dwa Sławy to artyści, którzy prawdopodobnie najczęściej w polskim hip-hopie wprowadzają do swoich tekstów elementy intertekstualne. Po drugie, bardzo silnie eksperymentują z formą, inspirują się przy tym innymi raperami i stosują różnorodne techniki ${ }^{29}$. Co więcej, wpisują się w newschoolowy odłam polskiego hip-hopu: tworzone przez nich podkłady muzyczne wyłamują się i przekraczają schematy ortodoksyjnego rapu ${ }^{30}$. Oznacza to również, że Dwa Sławy zwracają uwagę na

28 Zespół powstał w 2006 roku, a jego nazwa pochodzi od powtarzającej się ostatniej sylaby w imionach członków. W jego skład wchodzi Jarosław "Astek" Steciuk i Radosław "Rado Radosny" Średziński. Zadebiutowali w 2007 roku albumem Dla sławy, jednak to dopiero piąta produkcja, czyli Ludzie sztosy z 2015 roku, przyczyniła się do ich sukcesu (wzrosły: sprzedaż płyt i biletów na koncerty, liczba wyświetleń ich piosenek na youtubie, zainteresowanie wywiadami z nimi oraz częstotliwość koncertów) i ugruntowała ich miejsce na polskiej scenie hiphopowej. Mówi się, że Dwa Sławy tworzą comedy rap, czyli taki podgatunek hip-hopu, który silnie operuje formą i ma na celu tworzenie humorystycznych i satyrycznych obrazów rzeczywistości, w tym środowiska hiphopowego.

Zob. przypis 26. Dodatkowo należy wspomnieć, że Dwa Sławy w wywiadach wypowiadają się na ten temat i stwierdzają, że bycie dobrym raperem polega przede wszystkim na byciu dobrym obserwatorem. Przyznają się do tego, że inspirują się ("kradną") innymi hiphopowcami. Łączy się to właśnie z tworzeniem comedy rapu, który - w założeniu - parodiuje raperów.

Mowa tu o podstawowym podziale rapu na oldschool i newschool. Oldschool to pierwszy chronologicznie rodzaj hip-hopu, utrzymujący się w Stanach Zjednoczonych do połowy lat 8o., potem następuje era newschool'u. W Polsce pierwszą płytą newschoolową jest płyta Eisa Gdzie jest Eis? z 2003 roku. Jednak pozostaje ona szerzej niezauważona, dopiero po latach staje się podstawową inspiracją dla polskiej szkoły newschoolowej. Zdecydowanie inaczej dzieje się z newschoolową płytą Pezeta Radio Pezet. Produkcja Sidney Polak z 2013 roku, która zostaje ostro skrytykowana przez raperów oldschoolowych. Niemniej jednak to mniej więcej wówczas rozpoczyna się intensywny rozwój newschoolu w Polsce. Te dwa odłamy hip-hopu różnicują: sample (oldschool to proste brzmienia - newschool wprowadza złożone schematy rytmiczne i korzysta z muzyki elektronicznej, dubstepowej, syntetyzatorów, przesterów etc.), tekst (oldschool to proste kompozycje rymowe; nacisk kładzie na przekaz - dominantą w newschoolu jest indywidualne, charakterystyczne flow, które organizuje tekst). Tematycznie, jak i intertekstualnie, wczesny rap odwołuje się do innych utworów hiphopowych oraz do doświadczeń blokowiskowych. Teksty newschoolowe podejmują ogólne społeczne wątki. Oczywiście taka klasyfikacja nie oznacza, że w obecnej chwili mamy do czynienia z sytuacją, w której brakuje płyt oldschoolowych. Jest wręcz przeciwnie: te dwa odłamy z jednej strony oddziałują na 
szersze - niż tekściarze oldschoolowi ${ }^{31}$ - spektrum społecznych problemów, co ma niebagatelny wpływ na przywoływane w ich utworach hipoteksty. Artyści będą często odnosić się do popkultury32: do memów i filmów (np. w Niskiej szkodliwości społecznego czynu ${ }^{33}$ przywołują scenę kłótni Adasia Miauczyńskiego z sąsiadką z Dnia świra Marka Koterskiego i zastępują słowo "pies" słowem „pieseł”; tym samym dynamizują język hip-hopu), popularnych polskich programów telewizyjnych (np. w Człowieku sztosie ${ }^{34}$ parafrazują wers z utworu List motywacyjny ${ }^{35}$, w którym nawiązywali do Lisa i kozła Adama Mickiewicza, i zmieniają jego znaczenie przez odesłanie do bohatera programu MTV, co skutkuje ponownie aktualizacją lingwistyczną, ale i wskazuje na postulowaną procesualność obrazów kultury) czy do znanych piosenek (np. utwór Estrogen ${ }^{36}$ jest polemiką z piosenką Kayah Testosteron ${ }^{37}$ i prze-pisaniem tekstu kobiecego przez podmiot męski). Odniesienia do popkultury w przeważającej części są mocno osadzone kontekstowo, przywołane wprost lub wyodrębnione kompozycyjnie za pomocą hashtagów, czyli wieloznacznych słów-kluczy, pojawiających się w klauzuli wersu i wyodrębnionych od jego poprzedniego segmentu przerwą na oddech. Hashtag to nie tylko element stylistyczno-konstrukcyjny ${ }^{38}$, ale przede wszystkim znaczące semantycznie miejsce, w którym zawsze pojawia się rozwijająca ogólne sensy utworu metafora i bardzo często nawiązanie intertekstualne. Ze względu na

siebie, a z drugiej trwają w stanie wojny. Problem ten w Polsce nie został szerzej opracowany. Zob. P. Edwards How to rap...; D. Toop Rap Attack 3: African Rap to Global Hip Hop, Serpent's Tail, London 2000; Antologia polskiego rapu, s. 41-54. (Hashtag zaznaczam poprzez odpowiadający mu znak pisarski. Nie istnieje ogólnie przyjęty wzór transkrypcji). Zob. Dwa Sławy Niska szkodliwość społecznego czynu, w: tegoż Ludzie sztosy, Embryo Nagrania 2015.

Zob. tamże.

To, co popkulturowe rozumiem przez pojęcie sztuki egalitarnej (jako obszar masowej kultury symbolicznej).

„Psooom się nie kłaniam, a witam się z gąską \#Trybson”. Zob. Dwa Sławy Człowiek sztos w: tamże.

5 "Nie kłaniaj się psom za to witaj się z gąską". Zob. Dwa Sławy List motywacyjny, w: tegoż, Nie wiem, nie orientuję się, Embryo Nagrania 2012.

Dwa Sławy Estrogen, w: tegoż Dandys flow, Embryo Nagrania 2017.

Kayah, Testosteron, w: tejże Stereotyp, BMG Poland 2003.

S. Wójtowicz O kierunkach..., s. 185. 
swoją jednoczesną złożoność i lapidarność, a także istotność interpretacyjną (w kontekście intertekstualności, ale i rapowej dialogiczności z kulturą) oraz naukowe nieopracowanie, technika ta również domaga się szerszego komentarza.

Hiperteksty w hashtagach pojawiają się w utworze Goździkowa, który tytułem odnosi się do znanego hasła reklamowego "Goździkowa przypomina na ból głowy Etopiryna”. W tekście zostają przywołane sytuacje, w których podmiot liryczny nie podejmuje pewnych codziennych aktywności (przesłuchania nagrania demo wręczonego przez fana; zawiezienia bliskich do szpitala etc.) z powodu bólu głowy. Slogan reklamowy funkcjonuje w przestrzeni internetu jako składnik memów, w których zamienia się pierwsze słowo z ostatnim. Semantyczne odwrócenie sprawia, że można go uznać za nośnik absurdu i metaforę zakłamania ${ }^{39}$. Dwa Sławy, wykorzystując symbolikę tytułu, wywracają dosłowny sens utworu i w efekcie piętnują społeczne relacje oparte na egoizmie i oszustwie. To pierwsze, wstępne spostrzeżenie okazuje się niezbędne do analizy i interpretacji hipertekstu w hashtagu:

Nie pojadę do Twoich rodziców, daj mi spokój

Zniszczenie wypisane na ryju \#Jared Joker

Zrób mi lepiej kawę kotku, prędzej

Niech postawi mnie do pionu \#Segway ${ }^{40}$

W zacytowanym fragmencie, podmiot odmawia odwiedzenia rodziców swojej dziewczyny, tłumacząc się przed nią bólem głowy, który prawdopodobnie spowodowany jest kacem, o czym informują dwa ostatnie wersy. Hipertekst odsyła do konkretnej realizacji Jokera, czyli do filmu Legion samobójców, w którym postać była grana przez Jareda Leto. Po pierwsze, mamy do czynienia z intertekstualną, dosłowną grą z informacją poprzedzającą nawiązanie: Joker miał wytatuowane na czole słowo damaged (zniszczony). Po drugie, z zaprzeczeniem jej na poziomie metaforycznym. W tym przypadku również z momentem autorskiej demaskacji. Imię Jared w transkrypcji jest bliskie imieniu rapera, wykonującego wersy (Jarek). Wprowadzenie elementu intertekstualnego w takiej formie nadaje uniwersalnemu znaczeniowo tekstowi

Potwierdza to również internetowa afera wywołana faktem, że Goździkowa „obecnie poleca wszystkim Etopirynę, aczkolwiek sama zażywa APAP". Zob. Goździkowa, w: Nonsensopedia na: http://nonsensopedia.wikia.com/wiki/Go\%C5\%BAdzikowa (20.02.2017). 
charakter indywidualny, ponieważ pozwala powiązać podmiot z autorem. Prywatyzacja przekazu łączy newschoolowy utwór hiphopowy z postulatami oldschoolu, w którym najważniejsze było konstruowanie tekstu w zgodzie $\mathrm{z}$ ideologią keepin' it real ${ }^{41}$, czyli - w uproszczeniu - utrzymywanie autentyczności wypowiedzi. Tak więc niemoralność przekazywana przez odesłanie do tzw. złoczyńcy wszech czasów cechuje równocześnie podmiot rapowy i społeczeństwo.W ten sposób (wskutek wprowadzenia informacji nacechowanej odwrotnie do dosłownego sensu) utwierdzona zostaje metaforyka tytułu. I po trzecie, hipertekst w postaci hashtagu aktualizuje się ponownie w rymującym się z nim wersie. Słowo "segway" ${ }^{\text {"2 }}$, które również jest hashtagiem, po analizie wszystkich trzech warstw nadaje utworowi umoralniającą puentę. Egoizm Jareda-Jarka zostanie wyparty przez altruistyczny czyn (ból głowy minie przez dziewczynę, która robi mu kawę), a wskutek zaakcentowania ludzkiej pracy, segway staje się mniej kontrolowaną komputerowo maszyną, a bardziej wytworem człowieka. Dotarcie do najgłębiej ukrytego, ale i esencjonalnego sensu utworu możliwe jest tylko dzięki interpretacji intertekstualności w hashtagach: raper wierzy w społeczną zmianę - a w Goździkowej zostaje przekazana pozytywna wizja rzeczywistości.

Trzystopniowy schemat dekodowania hipertekstu w hashtagach potwierdza się w Oho Dwóch Sławów, jednak w obręb tekstu zostaje wprowadzone nawiązanie w postaci follow-upu, co skutkuje niemożliwością pełnej interpretacji bez dostrzeżenia intertekstualności wewnątrzhiphopowej. Wiąże się to z problematyką utworu.

Oho, Dwa Słaby, bity to wiocha na rymach drewnianych

tym samym numer to wiocha zabita dechami

wszyscy tacy oryginalni są tutaj yy nie wiem

Ale żaden nie przebija Skorupa \#Shredder

To stare fajne ale gdzie nowe?

Projekt wyszedł, jest w drodze $\mathrm{u}^{43}$

Zob. K. Krakowski Disowanie: socjologiczna analiza konfliktów w hip-hopie, w: Hip hop w Polsce..., s. 63.

Dwukołowy pojazd z wbudowanym komputerem pokładowym odpowiedzialnym za utrzymanie równowagi. 
Utwór Oho stanowi polemiczną odpowiedź na negatywne komentarze słuchaczy. Dwa Sławy przywołują w nim typowe zarzuty odbiorców, z jakimi spotykają się wykonawcy hiphopowi ${ }^{44}$. W warstwie dosłownej wieńczą je ironicznie zarapowanym stwierdzeniem „oho", polemikę pogłębiają $\mathrm{w}$ warstwie metaforycznej i intertekstualnej. W zacytowanym fragmencie hipertekst odsyła do bajki animowanej Wojownicze żótwie ninja: Shredder to postać, która cały czas bezskutecznie próbuje pokonać żółwie ninja. Po pierwsze, nawiązanie do popkultury stanowi humorystyczną i dosłowną grę z pseudonimiem rapera Skorupy. Po drugie, zaprzecza przekazanej poprzednio informacji, ponieważ aktualizuje jej znaczenie. Po wprowadzeniu nawiązania, skorup może oznaczać żółwia ninja i nie odnosić się już do konkretnego rapera. Co więcej, hipertekst ponownie okazuje się momentem autorskiego ujawnienia, gdyż odsyła do innego utworu Dwóch Sławów Do ryma, w którym rapują: „pierdolę to zostaję ninja”. Na tym etapie intertekstualność nie staje się jeszcze elementem wywracającym dosłowny przekaz utworu, a wręcz potwierdza lekceważący stosunek raperów do słuchaczy i pogłębia polemikę rozpoczętą w warstwie dosłownej.

Po trzecie, kolejne rymujące się z hipertekstem (w postaci hashtagu) wersy jednocześnie ponownie nobilitują raperski status Dwóch Sławów (po raz kolejny ujawnia się braggadacio), ale i akcentują wagę słuchacza. $\mathrm{Na}$ przytoczone częste pytanie od fanów, odpowiadają, że „projekt wyszedł, jest w drodze". W tym wersie pojawia się inny hipertekst (follow-up), który odsyła do utworu duetu Płomień 81 z 2001 roku pod tytułem Projekt jest w drodze (nawiązanie do tytułu, ale i do refrenu: „Projekt jest w drodze nie tylko dla wynagrodzeń"45). Przekształcenie polega na dodaniu po pierwszym słowie czasownika „wyszedł” i ucięciu segmentu wersu pojawiającego się po hip-hopowej średniówce ${ }^{46}$. Hipertekst w tym wypadku okazuje się jednak nie ucięciem, ale kontaminacją wersu i skróceniem głównego przekazu utworu Płomienia 81, który w przeważającej części zbudowany był wokół techniki braggadacio ${ }^{47}$. Słowo „wyszedł" w potocznej semantyce sygnalizuje więc, że album się udał. Przez takie oddzielenie drugi człon hipertekstu nabiera

44 Widać to już w pierwszych wersach. Pojawiają się oskarżenia o toporne, niewyszukane rymy, brak oryginalności, niezbyt chwytliwy podkład muzyczny. Z tego rodzaju bluzgami wszyscy hiphopowcy spotykają się zawsze. 
znaczenia, które posiadał wycięty fragment z hipotekstu. Pojawia się również gra słowna - wyjść skądś, czyli być w drodze, co z kolei nasuwa na myśl zmierzanie dokądś, a więc i posiadanie celu. Jako, że w momencie odsłuchu płyta to zrealizowana całość, porównanie to nobilituje funkcję słuchacza to on jest finalnym i koniecznym dopełnieniem całego procesu twórczego. W ten sposób Dwa Sławy przemycają to, co Płomień 81 miał na myśli, pisząc „nie tylko dla wynagrodzeń". I ponownie hipertekstu w hashtagu prowadzi grę z tytułem oraz ujawnia esencjonalny sens tekstu: Dwa Sławy wcale nie lekceważą słuchacza słowem „oho”, wręcz przeciwnie - wskazują, że jest on integralnym elementem rapu.

Po analizie powyższych dwóch utworów ujawnia się kolejna cecha intertekstualności w rapie. W przypadku Goździkowej możliwe staje się odczytanie antyfrazowej konstrukcji utworu bez znajomości hip-hopu, w Oho nie. Okazuje się, że rap jest czytelny dla odbiorcy z zewnątrz tylko, gdy porusza ogólną problematykę społeczną. Natomiast jeśli odwołuje się do tematów wewnątrzśrodowiskowych, tworzy inkluzywną intertekstualność. W takim wypadku hipertekst w hashtagu dalej funkcjonuje jako metonimia, ale nie staje się antyfrazą. Zauważyć można jeszcze trzecią tendencję, czyli takie zestawienie intertekstualności wewnątrz - i pozahiphopowej, które wymaga od odbiorcy znajomości tylko jednej, opcjonalnej przestrzeni odwołań. Dotyczy to utworów podejmujących problem zarówno społeczny, jak i środowiskowy. Do tej grupy zalicza się Niska szkodliwość społeczna czynu, w której Dwa Sławy demityzują obraz rapera ${ }^{48}$ przez ironiczne przywoływanie sytuacji, w których ujawniają zachowania agresywne (dawanie lajków pod filmikiem na

48 W tym miejscu warto przytoczyć historię o tym, jak byli postrzegani raperzy w latach 9o. w Polsce. Gdy miał być organizowany pierwszy wielki festival hiphopowy, policja została poddana specjalistycznym szkoleniom. Otrzymali poradniki zatytułowane: Jak rozpoznać hiphopowca. W tej chwili wydaje się to być może śmieszne i absurdalne, ale warto jednak zauważyć ostracyzm społeczny skierowany w stronę tego środowiska. Artykuły, które wówczas powstawały na temat "chłopaków z osiedla" były przez swoją niewiarygodność równie zabawne, co krzywdzące. Prasa skupiała się na wandalizmie, przemocy, narkotykach i nieutylitarności społecznej tej grupy. Brak rzetelności dziennikarskiej odsłaniają liczne pomyłki np. pisano, że hiphopowcy noszą kurtki pękawki, co było prawdopodobnie refleksją konstruowaną w oparciu o amerykańskie wyobrażenia, bo wówczas to środowisko nie miało możliwości sfinansowania takiego zakupu. Podobnie rzecz ma się ze stereotypem powszechnego wciągania kokainy - na to też nie mieli pieniędzy. W broszurach przedstawiano raperów jako awanturników, osiedlowych chuliganów pełnych agresji. Z takimi właśnie przedstawieniami humorystycznie rozprawiają się Dwa Sławy. Zob. Blokersi [film], reż. S. Latkowski, Polska 2001; M. Miszczyński Wstęp, w: Hip-hop w Polsce..., s. 12-13. 
youtubie, przejechanie na czerwonym świetle, organizowanie bitwy na jedzenie etc.). Do aktów wandalizmu zalicza się także wycinanie serca na drzewie:

Jebana sąsiadka straszy mnie prokuraturą

Bo najebany zademonstrowałem, co takiego ważnego noszę pod skórą (chuja...)

Wycinam serce na drzewie, złapany strugam wariata \#Gepetto

Mamy diabelskie pomysły, taa, a limitem jest piekło ${ }^{49}$

Wers kończy się hipertekstem w hashtagu, który odsyła do bajki Pinokio. Po pierwsze, ponownie mamy do czynienia z dosłowną i humorystyczną grą z poprzedzającą informacją: podkreśla oddzielenie podmiotu od przyjętej pozy. Po drugie, po raz kolejny z polemiką z dosłownym sensem wersu ${ }^{50}$ (aktualizacja symboliki Gepetta przez wprowadzenie w nowy kontekst) i odesłaniem do tytułu (zwrócenie uwagi na fikcjonalność społecznych stereotypów). Podmiot wskutek przypadkowego ujawnienia uczuć przed inną jednostką zaczyna być owładnięty wstydem, czyli afektem zwiazanym ze stawaniem się, określaniem kim się jest ${ }^{51}$. Przed demaskacją chroni się przybraniem maski. Nie bez przyczyny bajkowe określenie Pinokia - „pajac” - zostaje zastąpione słowem „wariat". Na celową wymianę wskazuje semantyka obu rzeczowników, które w jednej z możliwych definicji oznaczają osobę zachowującą się niepoważnie, dziwacznie, inaczej. Jednak wariat to również zwrot na określenie osoby chorej psychicznie, czyli odstającej od przyjętej normy. Pojawia się ciekawy zabieg techniczny, który można by określić przewrotnością hiphopową, polegający na kontrastowym zestawieniu antytez: warstwy dosłownej i warstwy metaforyczno-interteksutalnej. W warstwie dosłownej podmiot rapowy nie utożsamia się ze społecznymi schematami (dewiacja - norma): świat podmiotu podporządkowany i tworzony przez obrazy społeczne, $w$ warstwie metaforyczno-intertekstualnej podmiot rapowy wyłamuje się z nienormatywnych schematów (norma - dewiacja): świat społeczny podporządkowany wizji podmiotu, wedle której ludzie to nieautentyczne, konformistyczne i obojętne wobec siebie kukiełki. Po trzecie, krytyka konformizmu zostaje

49 Dwa Sławy Niska szkodliwość...

50 Przywołany bohater czuł się nieszczęśliwy i samotny, więc wystrugał kukiełkę z magicznego drewna, a ta ożyła.

51 R. Leys Wstyd współcześnie, przeł. T. Bilczewski, A. Kowalcze-Pawlik, w: Afektywne historie i polityki pamięci, red. E. Wichrowska, A. Szczepan-Wojnarska, R. Sendyka, R. Nycz, Wydawnictwo IBL PAN, Warszawa 2015, s. 349-401. 
podjęta również w rymującym się z hipertekstem (hashtag) wersie, w którym pojawia się nawiązanie w postaci follow-upu do utworu Sky's the limit Notorious'a B. I. G.:

Sky is the limit and you know that you can have what you want, pressin what you want

Sky is the limit and you know that you keep on Just keep on pressin on Sky is the limit and you know that you can have what you want, be what you want, have what you want, be what you want ${ }^{52}$

Dwa Sławy, zamieniając „niebo” na „piekło”, ponownie posiłkują się kontrastowym zestawieniem i naprowadzają na odwrotne odczytanie refrenu Notoriousa, który w jednej z możliwych wersji brzmiałby tak:

Piekło to limit, a ty wiesz, że nie możesz mieć, tego co chcesz, nie zmierzasz tam gdzie chcesz Piekło to limit, a ty nie próbujesz być ponadto nie brniesz ponadto Piekło to limit, a ty nie możesz mieć tego co chcesz, być kim chcesz, mieć czego chcesz, być kim chcesz

Refren komentowałby wówczas opresywność sytuacji konformistycznej, a zrymowanie słowa „Gepetto” ze słowem „piekło”, ponownie ironicznie demaskowałoby i krytykowałoby społeczne normy. W wersie poprzedzającym wers z hashtagiem odbiorca zostaje odesłany do kolejnego utworu hiphopowego: Skóry Te-Trisa, w którym raper również podejmuje temat życia à rebours: „Pod skórą tylko siebie mam, nikogo więcej”53. Dwa Sławy przywołują refren: "Jeśli to masz, to ludzie to czują / Bo najważniejsze to, co nosisz pod skórą"54, rapując, że pod skórą noszą „chuja”. Z jednej strony jest to dosłowne nawiązanie do sytuacji poprzedzającej nawiązanie intertekstualne, czyli może oznaczać ekshibicjonizm - pokazanie napletka lub penisa, jeśli przyjmiemy, że skóra to materiał, z którego wykonane są spodnie. Wówczas łączyłoby się

\footnotetext{
52 Notorious B.I.G. Sky's the limit, w: tegoż Life after death, Big Beat Records 1997.

53 Te-Tris Skóra, w: tegoż LOT 2011, Aptaun Records 2011.

54 Tamże.
} 
to z częstym w rapie manifestowaniem męskiej dominacji55. Z drugiej strony odsyła również do tytułowego procesu destereotypizacji obrazu rapera, co wskazuje na ekshibicjonizm nie ciała, ale duszy: pijackie zwierzenie się przed sąsiadką. „Chuj” byłby wówczas elementem autokrytycznym, odkształcającym metaforykę utworu Te-Trisa, który w Skórze odwraca powiedzenie „mieć diabła pod skórą" na rzecz „mieć siebie pod skórą”. Jednak po powiązaniu z refrenem: „To nic, to nic / Nie znaczyło nic do chuja"56 autodemaskacja okazuje się pozorna. „Chuj” oznacza również tyle, co nic. W warstwie intertekstualnej na drugim i trzecim poziomie zostaje przeprowadzona krytyka konformizmu i stereotypizacji. Głos podmiotu, czyli podjęta próba ukazania zjawisk, ale i chęć wywołania zmiany w myśli społecznej, jest słyszalny oraz możliwy do intertekstualnego zinterpretowania dla odbiorcy związanego i niezwiązanego kulturowo z rapem.

\section{Wnioski}

Ukazana przeze mnie propozycja interpretacji i analizy praktyk intertekstualnych w rapie jest zaledwie szkicową próbą podjęcia tego tematu na gruncie polskiego hip-hop studies. Wnioski płynące z artykułu można rozpatrywać dwupłaszczyznowo.

Po pierwsze są to konkluzje literaturoznawcze. Należy zauważyć, że rap operuje własnymi technikami i definicjami. Proponuję włączyć do badań nad intertekstualnością definicje follow-upu jako świadomego i najczęściej pozbawionego ramy kontekstowej odniesienia w hipertekście hiphopowym do hipotekstu hiphopowego, które polega na cytowaniu lub parafrazowaniu wersu/wersów, ponieważ zostaje on wprowadzany w tekst zupełnie inaczej niż inne odniesienia: nie posiada ramy kontekstowej, wymaga często pełnej znajomości hipotekstu. Natomiast badane przeze mnie odwołania do popkultury są wyraźnie zaznaczone w hipertekście: przywoływane w taki sposób, aby odbiorca mógł zauważyć „obcy” element. Odbywa się to przez nawiązanie do tytułu, bohatera, autora, wprowadzenie obcojęzycznego słowa czy wyodrębnienie kompozycyjno-stylistyczne w postaci hashtagu. Hashtag

55 "A certain belief animates the poetry: the confidence that rhyme serves as a powerful tool for sexual enticement. In short, rhyme seduces. To carry erotic power, words must embody desire's force, not simply transcribe it [...] a song may seduce even when its words seemingly describe a hopelessly unsexy situation." - D. Caplan Rhyme's Challenge, s. 83. 
z definicji (wieloznaczne słowo-klucz, występujące na końcu wersu i wyodrębnione od poprzedniego segmentu przerwą na oddech) nie jest elementem zawierającym nawiązanie intertekstualne, lecz - jak można zauważyć - raperzy włączają w jego obręb również takie odniesienia. $Z$ tego powodu interpretacja celowego zabiegu technicznego należy do problemów, związanych $\mathrm{z}$ badaniem intertekstualności w rapie. Można zauważyć, że odczytywanie hipertekstu w hashtagach wymaga trójpoziomowej analizy. Po pierwsze, jest to element dosłownej, językowej gry z informacją zawartą w pierwszym członie wersu. Po drugie, polemika z pojawiającą się przed nim informacją oraz jej aktualizacja semantyczna. I po trzecie, hashtag wiąże się z rymującym się z nim wersem, co w efekcie skutkuje nową interpretacją à rebours. W drugiej i trzeciej warstwie hiperteksty zyskują aktualizację semantyczną, są momentem ujawnienia się autora, stanowią antyfrazę, odwołują się do tytułu i innych nawiązań intertekstualnych.

Po drugie, artykuł przynosi również wnioski kulturoznawcze. Jak wynika z artykułu, hiphopowa intertekstualność nie jest tylko zabiegiem czysto estetycznym czy znaczącym momentem semantycznym, wywracającym pozaintertekstualny sens utworu, ale i elementem zawierającym autorski zwrot do adresata, przez który raperzy ingerują w myślenie odbiorcy. W Goździkowej przekazują słuchaczowi nowe wzorce tożsamościowe, w Oho odpowiadają na pojawiające się często pod filmikami czy postami na facebooku komentarze fanów, w Niskiej szkodliwości społecznego czynu nie tyle rozprawiają się ze zastanymi stereotypami, co budują nowe reprezentacje społecznych obrazów. Na ingerencję w schematy społeczno-kulturowe wskazują również przekształcenia i aktualizacje językowe innych tekstów kultury. Co więcej, o ile wczesny hip-hop najczęściej opisuje podwórkowe życie i problemy środowiskowe, a intertekstualnie odwołuje się głównie do polskiego lub amerykańskiego hip-hopu, o tyle w hip-hopie newschoolowym poruszane problemy stają się często problemami społecznymi, a elementy intertekstualne pochodzą w równej mierze z rapu, co z innych tekstów kultury w tym popkultury. Przykładowo w Goździkowej można znaleźć cztery wyraźne nawiązania intertekstualne do utworów hiphopowych i cztery (mocno zasygnalizowane) odnoszące się do tekstów kultury popularnej - w rapie oldschoolowym odnaleźlibyśmy prawie zawsze tylko hipoteksty hiphopowe. Można więc uznać, że najnowszy hip-hop przestaje być zamkniętą enklawą ${ }^{57} \mathrm{i}$ otwiera

57 Chodzi o pierwotny postulat elitarności. M. Vecchi La cultura hip-hop e la musica rap in Italia, Milano 2012, ebook na: http://www.donermusic.it/La\%2ocultura\%2ohip\%2ohop\%20e\%20 
się na szersze grono odbiorców m.in. przez pozwolenie im na partycypację $\mathrm{w}$ intertekstualnej grze. Wiąże się to również z przywoływanymi w utworach doświadczeniami, co wskazuje na to, że tożsamość rapowa podległa redefinicji. Mowa tu o rozszerzeniu egzystencjalno-przestrzennym: z życia w obrębie wspólnoty blokowisk w stronę życia w obrębie wspólnoty narodowej. Wnioski te można udowodnić konkretnymi przykładami, ponieważ wydaje się, że m.in. intertekstualne otwarcie Dwóch Sławów w Dandys Flow przyczyniło się do zwiększenia ich marketingowego sukcesu. Płyta tuż po premierze na tydzień uplasowała się na 1. miejscu OLiS ${ }^{58}$, co jest sporym sukcesem jak na płytę hiphopową, a tym bardziej utrzymaną w stylistyce newschoolu, którym pogardza spora część wieloletnich słuchaczy polskiego rapu $^{59}$. W rankingu w latach 2000-2009 tylko trzy płyty hiphopowe zajęły pierwsze miejsce (łącznie figurowały na niej cztery tygodnie), a momentem znaczącym był przełom lat 2012/2013, czyli wydanie przez Donatana Równonocy. Stowańskiej duszy (pierwsze miejsce przez cztery tygodnie), lecz dopiero w 2016 roku można zaobserwować zwiększone zainteresowanie rapem, gdy aż czternaście albumów osiągnęło pierwszą pozycję (łącznie przez dziewiętnaście tygodni) ${ }^{60}$. Pokazuje to dwukierunkowy proces komunikacyjny między artystami a ich słuchaczami: twórcy wychodzą ze swojego pierwotnego „środowiska blokowisk" m.in. intertekstualnie wskutek czego wzrasta ich popularność - rap poszerza swoje grono odbiorcze. Jednak - jak można wnioskować po analizie wprowadzeń intertekstualnych - hip-hop z jednej strony adresuje swoje teksty do większej części społeczeństwa, lecz z drugiej wciąż prowadzi wewnętrzną rozmowę: przyłączyć się mogą do niej tylko Ci, którzy zechcą go poznaćc1. Dowodów na istotną rolę intertekstualności należy szukać na takich portalach jak szopenrapu.pl czy genius.com, na których

la\%2omusica\%2orap\%2oin\%2oltalia\%20-\%20Massimiliano\%2oVecchi.pdf (20.03.2017), s. 34, $39,48$.

58 Zestawienie sprzedaży płyt w Polsce.

59 Zob. przypis 30.

60 Zob. J. Sobczyński To sq̨ wszystkie rapowe albumy, które trafiły na 1. miejsce OliS (23.05.2017) na: http://newonce.net/2017/05/to-sa-wszystkie-rapowe-albumy-ktore-trafily-na-1-miejsceolis/ (29.05.2017).

61 Zob. tamże, ale i wniosek ten wynika już z samej proweniencji terminu "hip-hop": pierwszy człon można przełączyć jako "aktualne", a drugi wskazuje na "skok". Jak pisze Massimiliano Vecchi, oznacza to, że rap za cel obiera sobie jednoczesne wyrażanie i przekształcanie rzeczywistości. Zob. M. Vecchi La cultura..., s. 4. 
to słuchacze dekodują teksty, dochodząc przy tym do często niesamowicie owocnych interpretacji. Intertekstualność - również w hip-hopie - jest podstawowym elementem relacyjnym między podmiotem twórczym a odbiorcą i zachętą do partycypacji w ciągłym dialogu kulturowym, popkulturowym, subkulturowym, pozatekstowym.

\section{Abstract}

\section{Adrianna Chorąży}

JAGIELLONIAN UNIVERSITY (CRACOW)

Hip Hop Intertextuality as Dialogue: Rap and Pop Culture in Follow-Ups and Hashtags

This article explores intertextuality in contemporary Polish rap (Dwa Sławy) by examining hip hop techniques that create intertextual references such as follow-ups and hashtags. Chorąży's conclusions bear on literary studies (patterns for deciphering hashtags, the definition of the follow-up) as well as cultural studies. Focusing on references to pop culture and other rap texts, Chorąży argues that in most recent hip hop songs, intertextuality represents both a real dialogue with the audience and a subversive intervention in the thought patters of reception.

\section{Keywords}

hip hop, intertextuality, follow-up, hashtag, dialogue 